\title{
Introduction to Financial Caregiving and Glossary
}

PATTI C. WOOTEN SWANSON, Nutrition, Family, and Consumer Sciences Advisor, University of California Cooperative Extension, San Diego County; NANCILYNNE SCHINDLER, Staff Research Associate, University of California Cooperative Extension, San Diego County; and THOM T. TRAN, Staff Research Associate, University of California Cooperative Extension, San Diego County

\section{Overview}

The publications in this series are based on research conducted with adult child caregivers and caregiving professionals. The series provides practical insights and strategies for adult children (and other family members or friends) who are concerned about or caring for their aging, ill, or disabled loved ones. Financial caregiving tasks are organized and prioritized for caregivers according to three possible scenarios: when there is time to plan, when you observe that some assistance may be needed, and when there is a crisis. Caregiver resources include step-by-step implementation plans, consumer checklists, worksheets, and locations for finding more information. The series contains seven publications:

1. Introduction to Financial Caregiving and Glossary (Publication 8379)

2. Communicating with Your Parents about Finances (Publication 8380)

3. Getting Organized: Bill Paying and Record Keeping (Publication 8381)

4. Understanding Long-Term Care (Publication 8382)

5. Planning and Paying for Long-Term Care (Publication 8383)

6. Estate Planning (Publication 8384)

7. Financial Fraud and Abuse (Publication 8385)

The information presented in the Financial Caregiving Series is for general educational purposes only and is not intended to substitute for professional advice regarding legal, tax, or financial-planning matters.

\section{INTRODUCTION}

Ideally, the time to talk with your parents about their finances is when they are healthy-before they need assistance. But how do you bring up the subject and where do you start? Maybe you recently visited your parents and noticed stacks of unpaid bills or past due statements for important payments such as their home mortgage or health insurance. Should you step in to help? If so, where and how do you begin? What can you do if it seems obvious that they need assistance, but they deny the need and resist your efforts to help? Or 
"We took him, early on, to a financial planner and went through all of their CDs [certificates of deposit] and annuities, and their different banks and got all his paperwork that my mother had handled and my dad knew, kind of lined up so we could check and see when the CDs were coming due and get all that organized. So, fortunately, we worked with the financial planner and did that several years ago so now we are pretty on top of that."

-Caregiver, talking about how he assisted his father

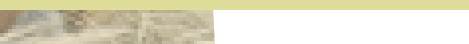

possibly your father, who has always managed your parents' finances, has had a health crisis such as a stroke, and you have unexpectedly been thrust into the role of financial caregiver. You need to make decisions, but you don't know much (if anything) about your parents' financial situation and preferences. Where do you start?

\section{Strategies for Getting Started}

Although every family's situation

is different, financial caregiving tasks are similar. "Where to start" (as a financial caregiver) depends on your parents' health and circumstances, as well as any prior financial planning they have done. The information and suggestions in this guide are organized according to three possible starting points for financial caregiving:

- when your parents are healthy and there is time to plan

- when you observe signs that your parents may need some assistance

- when a crisis occurs and you must step in to help your parents

Tables 1 to 3 (located near the back of this publication) present a broad overview of the relevant financial caregiving tasks in each of these three situations. The tables are organized according to the issues your parents will likely have to address as their needs change:

- communicating with family members about finances

- finding and organizing financial documents

- simplifying and streamlining money management

- choosing long-term care from the many available alternatives

- financing long-term care

- estate planning

- protecting themselves from financial fraud and abuse

\section{When Your Parents Are Healthy and There Is Time to Plan}

It is not unusual to be concerned about your parents' welfare as they age. For their sake as well as yours, you want to know that their financial and legal affairs are in order, and where to find important information in the event of an emergency. You may also want to encourage them to take steps to assure that their wishes are known, should they not be able to speak for themselves.

\section{Benefits of Advance Planning}

Advance planning can help you and your family avoid crisis decision-making; increase your parents' future options; save money; reduce sibling disagreements about "what Mom or Dad wants" and how their assets should be handled; and decrease the possibility that you (or your family) will have to take court action in order to manage your parents' financial affairs (Goetting and Schmall 2003; Schmall 2005).

Planning ahead can give your parents peace of mind because they know their wishes are understood and will be carried out. You can have peace of mind if you know what your parents want and you have the tools for caring and effective decision-making (AARP 1998; Timmermann 2001).

\section{Financial Caregiving Goals}

As a caregiver, there are two primary reasons for advance planning. The most important is to be prepared for an emergency by knowing where to find your parents' important financial and legal documents (FDIC 2003). A second reason for advance planning is to encourage your parents to prepare the financial and legal tools, such as a durable power of attorney, that will allow you (or another agent) to direct and manage their future financial affairs in the event that they cannot do so themselves.

\section{Caregiving Priorities}

- Initiate a discussion with your parents about their finances.

- Find out where they keep their personal and financial documents.

- Suggest simplifying day-to-day money management through direct deposit and automatic bill-paying services.

- Find out about their health insurance and where they keep their health ID cards.

- If your parents are eligible for Medicare, be sure they enroll in a timely way.

- Help your parents think about their needs and preferences for long-term care (should it be necessary). 
- Learn how your parents plan to pay for long-term care, and help them decide if they should buy longterm care insurance.

- Get their thoughts about qualifying for Medicaid for long-term care needs, and learn about any related financial planning they have done.

- If they have not already done so, encourage your parents to legally designate a "durable" power of attorney for finances and for health care.

- Discuss the importance of wills and estate planning.

- Learn about fraud targeting the elderly, so you and your parents can recognize and avoid scams.

- Ask about the type of medical care or life support your parents would want and encourage them to prepare advance directives specifying their wishes.

- Inquire about the type of funeral and burial they want, and learn about any related plans or purchases they have already made.

If your parents are healthy and independent, you don't need to know the specifics of their financial situation. The top priority is to find out where they keep their financial records and what they want you to do in an emergency situation. Reassure them you don't want to take control over their finances.

As you learn about your parents' financial plans (or lack of plans), you may not like or agree with their choices. If so, it may help to remember it is their money and they have the right to make their own financial and estate-planning decisions. If appropriate, encourage your parents to seek advice from a qualified professional such as an attorney, accountant, or financial planner. If they do not already have an advisor, offer to help them find one. This reassures them that you have confidence in

"And then she started having trouble with her checkbook and writing checks and voiding ten to write one and it got to the point where I would write them and she would sign them until that was not a good thing. -Caregiver, explaining how she recognized that her mother needed assistance their abilities to handle their own affairs.

\section{When You See Signs That Your Parents May Need Some Assistance}

Respect for your parents' independence and financial privacy may understandably make you reluctant to offer assistance, particularly if your parents insist "We're okay. We don't need any help." Even when the need becomes evident to others, you may be tempted to deny what you see because of the sadness it causes and the losses it represents.

\section{Warning Signs}

Generally, age-related changes come on gradually and are easy to miss if you are in daily or frequent contact with your parents. What should alert you that your parents may need assistance managing their finances?

One of the first signs of a problem could be piles of unopened bills at your parents' home. Or, you may see a number of overdraft notices from their bank or late notices for regular bills such as the mortgage, insurance payments, and utilities. If your parents start to complain about receiving a lot of calls from their creditors, this could indicate that they are forgetting to pay their bills. Or, if you happen to see the entries in your parents' checkbook register (for example, while you are shopping together) and they are meaningless or incomprehensible-this may indicate that cognitive impairment is affecting their ability to manage independently.

The Financial Planning Association (FPA 2006) advises adult children to watch for these "financial warning signs" that their parents may need help:

- Mismanaging their money: Watch for bills piling up at home, calls from creditors, and checks that haven't been deposited.

- Failing to file their taxes on time, or not filing them at all: Watch for letters from the Internal Revenue Service (IRS).

- Being victimized by financial scams: Look for checks made out to unfamiliar, out-of-state companies. Watch for piles of junk mail from contests, "free trips", sweepstakes, or items such as costume jewelry, pens and pencils, and cheap beauty products that may indicate they are buying worthless "valuable prizes."

- Evidence of financial abuse by caregivers or other family members: Take notice if your parents start avoiding you and other family members or friends, become secretive about their finances, and start relying only on their caregiver for advice.

- Buying unsuitable financial products: Be wary if your parents buy complex financial products they don't fully understand, or investments that are risky or inappropriate for their age, such as an annuity that will not begin payouts until they are 90 years old (for example, an annuity purchased when they are 75 years old that doesn't begin payouts for 15 years). 


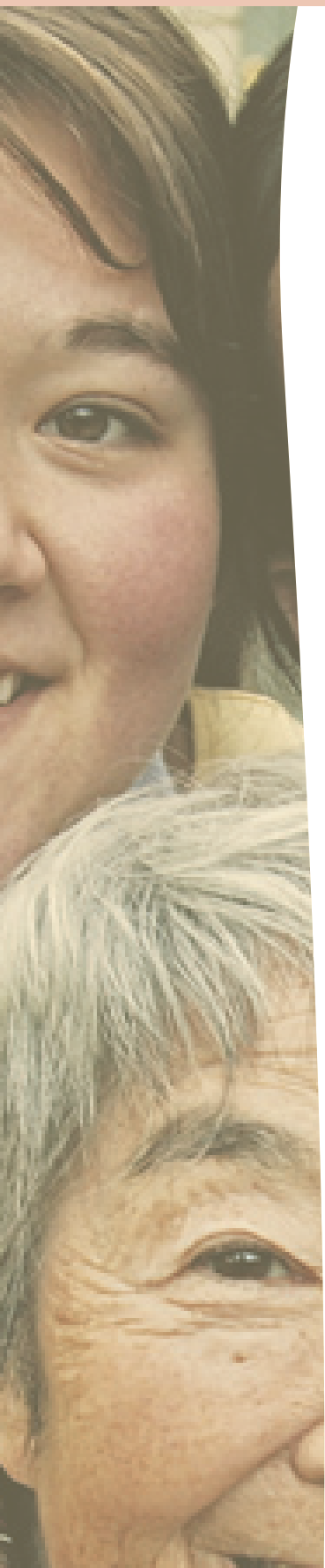

- Compulsive gambling: Watch for frequent trips to casinos, the use of credit cards for gambling, or constant talk about their "winnings." Online gambling may be more difficult to spot.

\section{Financial Caregiving Goals}

If you notice that your parents need assistance, there are two important steps to take. First, make sure all your parents' regular expenses are paid on time. Second, help your parents plan for their future health and financial needs, including facilitating the transfer of legal and financial authority to you (or another trusted family member or friend) in case of an emergency or future disability.

\section{Caregiving Priorities}

- Create a partnership with your parents so you can assist them as needed.

- Help your parents organize their financial and legal documents.

- Recognize the signs that your parents may need assistance.

- Make sure all bills, including health insurance premiums, are paid on time.

- If your parents are younger than 85 years old and in reasonably good health, help them decide whether or not to buy long-term care insurance.

- Ask your parents to legally designate someone to handle their financial affairs and make medical decisions for them in the event that they are too ill to make those decisions on their own (FPA 2006).

- Encourage your parents to prepare or update their wills.

- Discuss the importance of advance directives for health care.

- Take steps to protect your parents from fraud.

I ran into [the problem] that Social Security does not accept powers of attorney. You have to appear at a Social Security office with a letter from a doctor stating that that the person is incompetent to handle their affairs and then you become a representative of the payee [payee representative]. Unless you have that, you cannot do anything with Social Security.

-Caregiver, explaining how to work with the Social Security Administration

The answer depends on your parents' health status and financial situation. Often an elderly person is fully capable of financial decision-making and management, but illness or physical impairment limits their ability to actually perform financial management tasks. Some examples are

- limited physical mobility or driving restrictions that make it difficult or impossible for them to go to their bank or credit union (in person) for transactions such as cashing checks or buying certificates of deposit.

- reduced dexterity (due to arthritis, for example) that makes it difficult for them to write checks

- visual impairments that make it difficult for them to read credit card statements or other bills

In each of these situations only minimal assistance may be needed, such as giving your parents a ride to the bank, writing their checks for them to sign and mail, or helping them read their credit card statements and other bills. Encourage your parents to retain as much responsibility for their finances as they can, and only assist with tasks they cannot perform.

\section{When There Is a Crisis and You Must Step In To Assist Your Parents}

Sometimes adult children are suddenly and unexpectedly thrust into the role of financial caregiver when a parent suffers a heart attack, stroke, or other catastrophic health event. The need for caregiver assistance may be temporary (during recovery), or it may last for an indefinite period due to a severe illness, disability, or a progressive disease such as Alzheimer's.

\section{Financial Caregiving Goals}

When a crisis occurs, the immediate goal is to assess your parents' needs, financial resources, and options. If it appears that caregiving will be necessary for an extended or indefinite period of time, the primary goals will be to help your parents implement streamlined financial management systems, and take legal steps to facilitate the transfer of decision-making authority if the situation requires it.

\section{Caregiving Priorities}

- Get a professional assessment of your parents' condition and care recommendations (from their doctor or a hospital social worker) before making major financial decisions.
- Contact any financial advisors your parents have worked with in the past (such as bankers, lawyers, accountants, insurance agents, or financial planners). Ask for their recommendations about how to proceed and how they can assist you (FDIC 2003). 
- Get financial and legal advice from professionals you know and trust.

- Set up automatic deposit and bill-paying systems to simplify money management.

- Find and carefully review your parents' insurance coverage and government health benefits, such as Medicare and Medicaid.

- Try to make an accurate assessment of your parents' financial situation.

- Learn how you can access your parents' bank accounts and, if relevant, their brokerage accounts.

- Consider working with lawyers and financial advisors who specialize in helping the elderly.

- Encourage your parents to write or update their wills, appoint health-care proxies, and write advance directives.
- Be sure your parents have durable powers of attorney for finances.

Only mentally competent individuals can enact a power of attorney for finances, write a will, designate someone to make medical decisions on their behalf, or complete advance directives. If your parents become ill or disabled and have not already done so, it is essential to act immediately. Otherwise, if they become incapacitated or cognitively impaired, you may have to take legal action so that you (or someone else) can access their money to pay medical bills, conduct financial transactions on their behalf (such as selling their car or house), or determine the type of medical treatment they will receive.

\section{Selected Resources for Financial Caregivers}

\section{Publications}

Burns, S., and R. Forgue. 2003. How to care for your parents' money while caring for your parents: The complete guide to managing your older parents' finances and planning for their future. New York, NY: McGraw Hill.

FDIC (Federal Deposit Insurance Corporation). 2005. Fiscal fitness for older Americans: Stretching your savings and shaping up your financial strategies - A Special Guide for Seniors and Families. FDIC Consumer News, Fall edition. FDIC Web site, http://www.fdic.gov/consumers/consumer/ news/cnfall05/index.html.

\section{Web Sites}

AARP (www.aarp.org/families). This associationsponsored Web site offers family caregiving information and resources, such as a description of community services that help with caregiving, and guidelines for choosing an agency for in-home care. It also has information about financial management in later life, including housing choices, legal issues, estate planning, and financial powers of attorney.

Administration on Aging (www.aoa.gov). See the "Elders and Families" section of the Web site for information about issues facing older adults and the services available to assist them.
FPA (Financial Planning Association)

(www.fpanet.org). This Web site offers information to help individuals and families prepare for major life events. Go to "Financial Decisions for Life Events" and click on "Aging Parents" for information about making plans with your parents, costs of caregiving, finding an assisted-living facility for your parents, and more.

Senior Citizens' Resources at USA.gov (www.seniors.gov). This U.S. government Web site is devoted to empowering the elderly with knowledge about the variety of services available to them and helping users access all the government sites that provide services for senior citizens. It contains links to financial information for seniors, including retirement, health, housing, money management, consumer protection, and fraud.

National Caregivers Library (www.caregiverslibrary.org). This is a privately operated Web site that contains an extensive collection of articles, forms, checklists, and links to topic-specific external resources. The "Money Matters" section has information about financial caregiving issues such as assessing a loved one's finances and "delicate" financial situations, as well as information and checklists pertaining to housing (such as how to choose a nursing home), health insurance, Medicare and Medicaid, reverse mortgages, Social Security, and viatical settlements. 


\section{REFERENCES}

AARP. 1998. Talking about independent living. Research report. AARP Web site, http://www.aarp. org/research/housing-mobility/indliving/aresearchimport-803.html.

Administration on Aging (AoA). 2009. AoA Web site, http://www.aoa.gov/.

FDIC (Federal Deposit Insurance Corporation). 2003. Financial caregiving: A survival guide. FDIC Consumer News, Fall edition. FDIC Web site, http://www.fdic.gov/Consumers/consumer/news/ cnfall03/caregiving.html.

FPA (Financial Planning Association). 2006. Financial signs your elderly parents need help-and what to do about it. FPA Web site, http://www.fpaforfinancialplanning.org/LifeCrisis/CaringforaLovedOne/ FinancialSignsYourElderlyParentsNeedHelp/.
Goetting, M. A., and V. L. Schmall. 2003. Talking with aging parents about finances. Montana State University Extension Web site, http://msuextension.org/publications/ FamilyFinancialManagement/MT199324HR.pdf.

National Clearinghouse for Long-term Care. 2008. National Clearinghouse for Long-term Care Web site, http://www.longtermcare.gov/LTC/Main_ Site/index.aspx.

Schmall, V. L. 2005. Helping older family members handle finances. Corvallis: Oregon State University. Pacific Northwest Cooperative Extension Publication 344.

Timmermann, S. 2001. The changing needs of your aging parents: Have you talked to mom and dad lately? Journal of Financial Services Professionals 55(5): 36-38.

Table 1. Financial caregiving tasks: when there is time to plan

\begin{tabular}{|c|c|}
\hline Circumstances & Your parents are healthy and mentally capable. \\
\hline assessment & None required. \\
\hline \multicolumn{2}{|c|}{ FAMILY INTERACTIONS AND COMMUNICATION } \\
\hline family communication & $\begin{array}{l}\text { Initiate a dialogue with your parents about their finances. } \\
\text { Use the guidelines for positive communications in Part Two of this series. }\end{array}$ \\
\hline \multicolumn{2}{|l|}{ MONEY MANAGEMENT } \\
\hline financial records & Find out where your parents keep their financial and legal records. \\
\hline $\begin{array}{l}\text { day-to-day money } \\
\text { management }\end{array}$ & $\begin{array}{l}\text { Encourage your parents to consider direct deposit and automatic bill paying to } \\
\text { simplify financial management tasks. }\end{array}$ \\
\hline banking & Find out how you (as a caregiver) could access your parents' accounts, if necessary. \\
\hline financial planning & $\begin{array}{l}\text { Encourage continued savings and investments and suggest a consultation with a } \\
\text { financial planner. }\end{array}$ \\
\hline \multicolumn{2}{|c|}{ HEALTH INSURANCE AND LONG-TERM CARE } \\
\hline health insurance & Be sure your parents enroll in Medicare in a timely way. \\
\hline long-term care & Encourage your parents to consider buying long-term care insurance. \\
\hline housing/living arrangements & $\begin{array}{l}\text { If your parents own their home, encourage them to keep up with routine } \\
\text { maintenance and make needed repairs to preserve the value of the home. }\end{array}$ \\
\hline \multicolumn{2}{|l|}{ LEGAL MATTERS } \\
\hline powers of attorney & $\begin{array}{l}\text { Encourage your parents to consider appointing durable powers of attorney for } \\
\text { finances and medical care. }\end{array}$ \\
\hline wills and estate planning & Discuss the importance of wills and estate planning. \\
\hline end-of-life planning & Encourage your parents to consider setting up advance directives. \\
\hline fraud & $\begin{array}{l}\text { Guard against fraud: encourage your parents to be aware of potential scams and } \\
\text { skeptical of solicitations. }\end{array}$ \\
\hline \multicolumn{2}{|c|}{ PROFESSIONAL AND COMMUNITY SERVICES } \\
\hline $\begin{array}{l}\text { professional } \\
\text { advice }\end{array}$ & $\begin{array}{l}\text { If your parents have not worked with a financial professional such as an attorney, } \\
\text { accountant, or financial planner, this is a good time to find qualified professionals } \\
\text { who can assist as needed. }\end{array}$ \\
\hline community services & $\begin{array}{l}\text { Encourage your parents to participate in retirement and estate-planning programs } \\
\text { sponsored by employers or offered through adult education. }\end{array}$ \\
\hline
\end{tabular}


Table 2. Financial caregiving tasks: when assistance in managing money would be helpful

\begin{tabular}{|c|c|}
\hline Circumstances & $\begin{array}{l}\text { Financial problems arise from inaction or inappropriate financial } \\
\text { transactions, or a parent is diagnosed with a disease that causes cognitive } \\
\text { impairment. }\end{array}$ \\
\hline assessment & $\begin{array}{l}\text { You or other family members or friends recognize the problems, or a physician } \\
\text { makes a diagnosis. }\end{array}$ \\
\hline \multicolumn{2}{|c|}{ FAMILY INTERACTIONS AND COMMUNICATION } \\
\hline family communication & Talk with your parents to identify the problem(s) and offer assistance. \\
\hline \multicolumn{2}{|l|}{ MONEY MANAGEMENT } \\
\hline financial records & Locate your parents' financial and legal records and documents. \\
\hline $\begin{array}{l}\text { day-to-day money } \\
\text { management }\end{array}$ & $\begin{array}{l}\text { Work with your parents to implement a bill-paying system assuring that all bills are } \\
\text { paid on time. }\end{array}$ \\
\hline banking & $\begin{array}{l}\text { You and your parents should make arrangements so you can access their accounts } \\
\text { if necessary. }\end{array}$ \\
\hline financial planning & Develop a plan to pay for long-term care if and when it is needed. \\
\hline \multicolumn{2}{|c|}{ HEALTH INSURANCE AND LONG-TERM CARE } \\
\hline health insurance & Make sure your parents pay their health insurance premiums on time. \\
\hline long-term care & $\begin{array}{l}\text { Find out about your parents' preferences for long-term care (living at home with } \\
\text { assistance, nursing home, assisted living, or living with you). }\end{array}$ \\
\hline housing/living arrangements & $\begin{array}{l}\text { Help your parents acquire the necessary resources to live independently in their } \\
\text { own home as long as they want to and can do so safely. }\end{array}$ \\
\hline \multicolumn{2}{|l|}{ LEGAL MATTERS } \\
\hline powers of attorney & $\begin{array}{l}\text { Strongly encourage your parents to legally assign decision-making authority for } \\
\text { finances and health care. }\end{array}$ \\
\hline wills and estate planning & $\begin{array}{l}\text { Encourage your parents to prepare their wills and an estate plan. Encourage them } \\
\text { to plan for distribution of personal assets. }\end{array}$ \\
\hline end-of-life planning & $\begin{array}{l}\text { If they have not already done so, encourage your parents to set up advance } \\
\text { directives. }\end{array}$ \\
\hline fraud & $\begin{array}{l}\text { Help protect your parents from fraud by knowing about common schemes that } \\
\text { target the elderly. }\end{array}$ \\
\hline \multicolumn{2}{|c|}{ PROFESSIONAL AND COMMUNITY SERVICES } \\
\hline professional advice & $\begin{array}{l}\text { Consider working with financial professionals who specialize in helping the ill or } \\
\text { elderly. }\end{array}$ \\
\hline community services & $\begin{array}{l}\text { Find out what eldercare resources, services, and support options (public and } \\
\text { private) are available in your parents' community and any eligibility requirements. } \\
\text { Utilize state and federal programs to locate the medical care, personal care, and } \\
\text { other supportive resources that your parents need. }\end{array}$ \\
\hline
\end{tabular}


Table 3. Financial caregiving tasks: when assistance in managing money is essential

\begin{tabular}{|c|c|}
\hline Circumstances & Your parents are unable to capably function mentally or physically. \\
\hline assessment & $\begin{array}{l}\text { Get a professional assessment of your parents' condition as well as the type and } \\
\text { level of care needed. }\end{array}$ \\
\hline \multicolumn{2}{|c|}{ FAMILY INTERACTIONS AND COMMUNICATION } \\
\hline family communication & Share financial decisions with the family. \\
\hline \multicolumn{2}{|l|}{ MONEY MANAGEMENT } \\
\hline financial records & Review and organize your parents' financial and legal records. \\
\hline day-to-day money management & Set up automatic deposits and bill paying. \\
\hline banking & Be aware of the potential liabilities of joint accounts. \\
\hline financial planning & $\begin{array}{l}\text { Be aware of the laws regarding Medicaid qualification, and (if relevant) when it is } \\
\text { advisable to give assets and income to heirs. }\end{array}$ \\
\hline \multicolumn{2}{|c|}{ HEALTH INSURANCE AND LONG-TERM CARE } \\
\hline health insurance & Closely review your parents' insurance coverage and government benefits. \\
\hline long-term care & $\begin{array}{l}\text { Assess what resources your parents have to pay for long-term care. Select the best } \\
\text { care option based on the necessary level of care and the available resources. }\end{array}$ \\
\hline housing/living arrangements & $\begin{array}{l}\text { Find out what type of supportive housing is available in your parents' community } \\
\text { and compare options. If possible, take your parents to visit a facility before making } \\
\text { a decision. }\end{array}$ \\
\hline \multicolumn{2}{|l|}{ LEGAL MATTERS } \\
\hline powers of attorney & $\begin{array}{l}\text { If your parents are mentally competent, help them appoint durable powers of } \\
\text { attorney for finances and medical care. If not, seek court authority to access bank } \\
\text { accounts or authorization to make financial transactions on their behalf. }\end{array}$ \\
\hline wills and estate planning & $\begin{array}{l}\text { If your parents are mentally competent, encourage them to write or update their } \\
\text { wills. }\end{array}$ \\
\hline end-of-life planning & $\begin{array}{l}\text { Learn about your parents' funeral and burial preferences. If your parents have pre- } \\
\text { arranged plans, find out where the information and contracts are located. }\end{array}$ \\
\hline fraud & $\begin{array}{l}\text { Learn how to recognize signs that your parents might be victims of fraud, and be } \\
\text { alert to evidence of fraud or theft by caregivers or others. }\end{array}$ \\
\hline \multicolumn{2}{|c|}{ PROFESSIONAL AND COMMUNITY SERVICES } \\
\hline professional advice & Get advice from financial professionals who specialize in helping the ill or elderly. \\
\hline community services & $\begin{array}{l}\text { Use available eldercare resources, services, and support options in your parents' } \\
\text { community. Utilize state and federal programs to locate the medical care, personal } \\
\text { care, and other supportive resources that your parents need. }\end{array}$ \\
\hline
\end{tabular}




\section{GLOSSARY}

AAA. See Area Agency on Aging.

accessibility of services. The ability to get medical care and services when they are needed.

accessory apartment. A private housing unit that contains a kitchen and a bathroom that is created within, or next to, a single-family home.

activities of daily living (ADLs). Basic actions performed by an independently functioning person on a daily basis: (a) bathing; (b) dressing; (c) toileting; (d) transferring (moving to and from a bed or a chair); (e) eating; and (f) caring for incontinence. The need for assistance with ADLs or inability to perform ADLs is used to determine eligibility for many public programs such as Medicaid-reimbursed longterm care services.

ADL. See activities of daily living.

Administration on Aging. An agency within the U.S. Department of Health and Human Services dedicated to policy development, planning, and the delivery of supportive home and community-based services to older persons and their caregivers.

ADU. See accessory dwelling unit.

adult day care. Services provided during the day at a community-based center to meet the needs of functionally or cognitively impaired adults. Structured, comprehensive programs provide a variety of social, health, and support services in a protective setting during any part of a day, but less than 24-hour care.

Adult Protective Services. A state or community-based agency that investigates cases of suspected elder abuse, neglect, or endangerment.

advance directive (also called a living will). A legal document that dictates what medical decisions are to be made if the person loses the ability to make decisions, such as whether to be kept on artificial life support if permanently unconscious.

aging in place. The concept of allowing an older person to remain in the same residence as their care needs change, rather than requiring a move to another type of facility.

annuity. A contract made with an insurance company that provides monthly or interval cash payments for a fixed or variable time period.

Area Agency on Aging (AAA). State and local programs that help older people plan and care for their lifelong needs. Services typically include adult day care, skilled nursing care and therapy, transportation, personal care, respite care, and meals.

assessment. The process of gathering information to evaluate a person's health and personal care needs in order to plan for care.

assets. Property, including real property (land or buildings) and personal property (for example, cash, stocks, or vehicles) that belong to a person.

assisted living. A type of living arrangement in which personal care services such as meals, housekeeping, transportation, and assistance with activities of daily living are available as needed to people who still live on their own in a residential facility.

assistive technology. Tools or equipment that may be used by a person with a disability to perform specific tasks, improve functional capabilities, and become more independent. Examples include walkers, wheelchairs, hearing aids, andbeds that help a patient sit up.

beneficiary. The person who is entitled to receive the benefits under a will or a trust.

benefit trigger. A condition that must exist in order for an insurance company to pay benefits under a longterm care insurance policy.

board and care home (also called a group home). A private residential home that provides housing, meals, housekeeping, and personal care services to frail or disabled residents.

care or case management. Health care professionals (typically nurses or social workers) who specialize in assisting elders and their families with arranging, coordinating, and managing long-term care services.

caregiver. A generic term referring to a person, either paid or volunteer, who helps an older person with the activities of daily living, health care, financial matters, guidance, companionship, and social interaction. A caregiver can provide more than one aspect of care. Most often the term refers to a family member or friend who aids the older person. 
care plan. A written plan for a person's care that specifies what services they will receive to reach and maintain their optimal physical, mental, and social well-being.

CCRC. See continuing-care retirement community.

Centers for Medicare and Medicaid Services (CMS). The federal agency that runs the Medicare and Medicaid programs and maintains a Web site with information, resources, and eligibility guidelines for the programs.

certified. A long-term care facility, home health agency, or other provider that meets the official Medicare and Medicaid requirements.

chore services. Services provided in the home that may include meal preparation, housekeeping, transportation, and shopping.

CMS. See Center for Medicare and Medicaid Services.

codicil. A legal supplement or addition to an existing will that explains, modifies, adds to, subtracts from, qualifies, alters, or revokes existing provisions in a will.

cognitive impairment. Deterioration of intellectual ability, such as disorientation to people, places, or time; impairment of short-term or long-term memory; or impairment of one's ability to reason, that has progressed to the extent that a person requires substantial supervision.

congregate meals. Programs that provide older individuals with free or low cost, nutritionally sound meals served in a group setting.

conservator. A court-appointed agent who is legally authorized to make financial decisions for another person who is legally deemed as incompetent. In some jurisdictions the term is used synonymously with the term guardian.

continuing-care retirement community (CCRC). A retirement complex that offers a range of housing, services, and levels of care all in one location, including independent living units, an assisted living facility, and a nursing home. Residents move among the facilities as their health and personal needs dictate.

continuum of care. A comprehensive system of long-term care services and support systems in the community, as well as in institutions. The continuum includes: community support services such as senior centers; in-home care, such as home-delivered meals, homemaker services, home health services, shopping assistance, personal care, chore services, and friendly visiting; community-based services such as adult day care; noninstitutional housing arrangements such as congregate housing, shared housing, and board-and-care homes; and nursing homes and acute facilities if necessary.

custodial care (also called personal care). Nonskilled personal care, such as help with activities of daily living like bathing, dressing, eating, getting in or out of a bed or chair, moving around, and using the bathroom.

dementia. Deterioration of mental abilities such as vocabulary, abstract thinking, memory loss, judgment, and physical coordination that interferes with one's daily activities.

discharge planner. A social worker or other health care professional who assists .patients and their families in moving from the hospital to another level of care such as home health care in the patient's home or a skilled nursing facility.

durable power of attorney (POA). A legal document that designates another person (called the attorneyin-fact) to act on one's behalf, in the event that one becomes incapacitated and unable to make decisions for oneself.

elder abuse. Any knowing, intentional, or negligent act by a caregiver or any other person that causes harm or a serious risk of harm to a vulnerable adult. Abuse may be physical, emotional, financial, or sexual, and it may involve exploitation, neglect, or abandonment.

elder law attorney. An attorney who practices in the specialized area of law focusing on issues that typically affect older adults and their families.

end-of-life decisions. Decisions about life-saving medical procedures, burial and funeral arrangements, and power of attorney for health care.

estate. The total value of all assets a person owns, including a home, investments, retirement savings, and life insurance policies, as well as personal property such as jewelry, vehicles, and tools. 
estate planning. The process of organizing one's financial affairs so that money, property, and other assets can go to heirs with a minimum of costs, taxes, and legal barriers.

estate taxes. Taxes assessed against the net assets of an estate, which must be paid by the administrator from the estate's assets. These taxes are levied at death, based on the value of property left behind.

exclusion. Any condition or expense that a health or long-term care insurance policy will not pay.

executor. The person or entity named in a will that has the responsibility of carrying out the terms of the will, including collecting the deceased's assets, paying outstanding debts, and distributing the remaining assets to the beneficiaries.

Federal Housing Administration (FHA). An agency of the U.S. Department of Housing and Urban Development (HUD) that insures Home Equity Conversion Mortgage (HECM) loans (reverse mortgages).

FHA. See Federal Housing Administration.

friendly visitor and telephone reassurance. Community services that provide regular personal or telephone contact for older persons who are homebound or live alone.

geriatric care managers. Specially trained social workers or health care providers that provide case management services to individual clients and their families.

guardian. A court-appointed agent that has legal authority to manage a person's financial and/or personal affairs because that person is not competent to manage his or her own affairs.

health-care power of attorney. A legal document used to name someone (referred to as an agent or proxy) to make health care decisions for another person, if that person is unable to make or communicate those decisions for himself or herself.

\section{HECM. See Home Equity Conversion Mortgage.}

heir. Someone who receives assets from the estate of a person who has died.

home and community-based services. A variety of supportive services delivered in community settings or in an older person's home, to enable the care recipient to continue to live independently and avoid institutionalization.

home equity. The value of a home minus any money owed on the home mortgage.

Home Equity Conversion Mortgage (HECM). The only reverse mortgage program insured by the Federal Housing Administration, a federal government agency.

Home Health Agency. An organization that provides medical and personal care in the home, such as skilled nursing care, physical therapy, occupational therapy, speech therapy, and personal care, administered by home health aides.

home modification. Adaptation or renovation to the living environment that increases ease of use, safety, security, and independence for the resident.

homemaker service. In-home services to assist individuals with tasks such as light housekeeping, laundry, grocery shopping, meal preparation, and shopping assistance.

hospice. A philosophy and practice of caring for terminally ill patients and their families that provides comfort,pain medication, spiritual care and non-life-saving medical care to the terminally ill in their own home.

HUD. See Federal Housing Administration.

incapacitated. A term used to describe a person who lacks the ability to make decisions concerning health care and/or personal matters. The incapacity may be mental (cognitive impairment) or physical (effects of a stroke).

incompetent. A legal term describing someone who lacks the mental or emotional capacity to make his or her own decisions.

independent living. A type of senior retirement housing within the community that typically does not provide health-care services.

inflation protection. An insurance policy option that automatically increases benefits to help pay for expected increases in the cost of long-term care.

inheritance tax. A tax assessed against the beneficiaries of an estate based on the amount received by each beneficiary and that beneficiary's relationship to the deceased. 
inpatient care. Health care that includes at least an overnight stay in a hospital or other health-care facility.

instrumental activities of daily living (IADLs). Core life activities of independent living, including using the telephone, managing money, preparing meals, doing housework, and remembering to take medications.

intestate. The state or condition of dying without having made a valid will.

joint account. A bank account with two or more owners that provides equal or unrestricted access to the funds for all owners.

letter of last instructions. A detailed list of everything a survivor needs to know in order to handle the deceased's immediate personal and financial affairs, and may include funeral plans, a list of family and friends to be contacted upon death, information regarding the location of the will or other legal documents, content for the obituary, and personal notes to survivors. It is not a legal document and does not substitute for a will.

life-care contract. A written agreement to provide personal and medical care for the resident of a continuing-care retirement community for the rest of his or her life, in exchange for a significant up-front payment (sometimes called an entry fee).

living will. A legal document (also called a medical directive or advance directive) that states a person's wishes regarding life-support or other medical treatment in certain circumstances, usually when death is imminent.

long-term care (LTC). A variety of services that includes medical and nonmedical care for someone with a chronic illness or disability. Long-term care can be provided at home, in the community, or in various types of residential facilities, such as assisted-living residences and skilled nursing facilities.

long-term care insurance (LTCI). A private insurance policy that pays for some long-term medical and nonmedical care costs, like help with activities of daily living and extended nursing-home care.

LTC. See long-term care.

LTCI. See long-term care insurance.

Meals on Wheels. A community-based program that delivers nutritious meals to people who are homebound and do not have outside assistance.

Medicaid. A joint federal and state program that helps with medical costs for some people with low incomes and limited resources. Medicaid programs vary from state to state.(In California, Medicaid is called Medi-Cal.)

Medicare. A federal health insurance program for people age 65 or older, certain younger people with disabilities, and people with End-Stage Renal Disease.

Medigap policy (Medicare Supplemental Insurance). Insurance policies sold by private insurance companies to fill "gaps" in the original Medicare Plan coverage, such as deductibles, prescription drugs, or other services not covered by Medicare.

neglect. A situation that occurs when caretakers do not give a person in their care the goods or services needed to avoid harm or illness.

nonforfeiture benefits. A feature of some long-term care insurance policies that provides paid-up, longterm care coverage for a shortened benefit period if payments lapse.

nursing home (also called a skilled nursing facility). A residential care facility for people who require daily assistance and/or supervision because of physical or mental problems that prevent them from living independently.

occupational therapy. Services given to help a person return to usual activities such as bathing, preparing meals, and housekeeping after an illness.

out-of-pocket costs. Health-care or long-term care costs that a person pays when receiving care even though the person is insured.

outpatient care. Medical or surgical care that does not include an overnight hospital stay.

PACE. See Programs of All-inclusive Care for the Elderly. 
personal care (also called custodial care). Non-skilled service or care, such as help with bathing, dressing, eating, getting in and out of bed or chair, moving around, and using the bathroom. It may also include care that most people do themselves, such as administering eye drops.

personal property. Nontitled property personal belongings that may have sentimental or monetary value, including items such as wedding photos, jewelry, tools, artwork, or family momentos.

plan of care. A written plan provided by a doctor, social worker, or geriatric care manager describing what kind of services and care an individual needs for a particular health problem.

POA. See durable power of attorney.

power of attorney. A legal document that appoints someone to make decisions about medical care for another person.

pre-existing condition. A health condition for which medical advice or treatment was recommended by or received from a health care provider within a stated time period prior to the effective date of insurance coverage (for example, 6 to 12 months).

probate. The court process in which a will is determined to be valid and a deceased person's estate distributed in accordance with the terms of the will or the state's law of intestate succession.

Programs of All-Inclusive Care for the Elderly (PACE). A Medicare program for older adults and people over age 55 living with disabilities that provides community-based care and services to people who would otherwise need nursing home level of care.

proprietary reverse mortgage. A private loan backed by the company that developed it (an alternative to a federally insured reverse mortgage).

qualified long-term care policy. A policy that conforms to federal law and offers potential federal tax advantages for some people.

residential care facility. A generic term for a group home, specialized apartment complex, or other institution that provides long-term care services where the individual lives.

respite care. Temporary care provided in a nursing home, assisted-living residence, or other type of long-term care program so that the usual caregiver can rest or take some time off.

reverse mortgage. A home loan that gives cash advances to a homeowner, requires no repayment until a future time, and is capped by the value of the home when the loan is repaid.

right of survivorship. A type of joint ownership where the surviving joint owner(s) gets title to the deceased's interest.

SAA. See State Agencies on Aging.

skilled nursing care. A level of care that includes services that can only be performed safely and correctly by a licensed nurse.

SNF. See skilled nursing facility.

skilled nursing facility (SNF). A nursing facility with the staff and equipment to give skilled nursing care and/or skilled rehabilitation services and other related health services.

State Agencies on Aging (SAAs). The designated agency within the state government that is responsible for administering a complex service system that complements and supports other human service systems in meeting the needs of the elderly.

State Insurance Department. A state agency that regulates insurance providers and products, and can provide consumer information about long-term care insurance.

TALC. See total annual loan cost.

total annual loan cost (TALC). The projected annual average cost of a reverse mortgage, including all itemized costs.

term life insurance. A life insurance policy that provides coveragefor $r$ a specified period of one or more years. It pays a death benefit only if the insured dies during the specified term.

universal design. Building design features and products for the home that make it safer and more comfortable for residents of all ages and for those with a disability.

whole life insurance. An insurance policy that builds cash value and covers a person for as long as he or she lives if premiums continue to be paid.

will. A document containing one's instructions and wishes as to how one's property and assets are to be distributed after one dies.

Sources: Administration on Aging 2009; National Clearinghouse for Long-term Care 2008. 


\section{ACKNOWLEDGMENTS}

This series was developed in part by gifts from the Dr. Zoe Anderson Stout Scholarship Fund and the California Association of Family and Consumer Science-San Diego District Scholarship Fund.

\section{FOR FURTHER INFORMATION}

To order or obtain ANR publications and other products, visit the ANR Communication Services online catalog at http://anrcatalog.ucdavis.edu or phone 1-800-994-8849. You can also place orders by mail or FAX, or request a printed catalog of our products from

University of California

Agriculture and Natural Resources

Communication Services

6701 San Pablo Avenue, 2nd Floor

Oakland, California 94608-1239

Telephone: (800) 994-8849 or (510) 642-2431

FAX: (510) 643-5470

E-mail inquiries: danrcs@ucdavis.edu

C2009 The Regents of the University of California

Agriculture and Natural Resources

All rights reserved.

No part of this publication may be reproduced, stored in a retrieval system, or transmitted, in any form or by any means, electronic, mechanical, photocopying, recording, or otherwise, without the written permission of the publisher and the authors.

\section{Publication 8379}

\section{ISBN-13: 978-1-60107-651-9}

The University of California prohibits discrimination or harassment of any person on the basis of race, color, national origin, religion, sex, gender identity, pregnancy (including childbirth, and medical conditions related to pregnancy or childbirth), physical or mental disability, medical condition (cancer-related or genetic characteristics), ancestry, marital status, age, sexual orientation, citizenship, or service in the uniformed services (as defined by the Uniformed Services Employment and Reemployment Rights Act of 1994: service in the uniformed services includes membership, application for membership, performance of service, application for service, or obligation for service in the uniformed services) in any of its programs or activities.
University policy also prohibits reprisal or retaliation against any person in any of its programs or activities for making a complaint of discrimination or sexual harassment or for using or participating in the investigation or resolution process of any such complaint.

University policy is intended to be consistent with the provisions of applicable State and Federal laws.

Inquiries regarding the University's nondiscrimination policies may be directed to the Affirmative Action/Equal Opportunity Director, University of California, Agriculture and Natural Resources, 1111 Franklin Street, 6th Floor, Oakland, CA 94607, (510) 987-0096. For information about ordering this publication, telephone 1-800-994-8849. For assistance in downloading this publication, telephone 530-754-3927.

To simplify information, trade names of products have been used. No endorsement of named or illustrated products is intended, nor is criticism implied of similar products that are not mentioned or illustrated.

An electronic copy of this publication can be found at the ANR Communication Services catalog Web site, http://anrcatalog.ucdavis.edu.

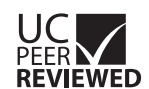

This publication has been anonymously peer reviewed for technical accuracy by University of California scientists and other qualified professionals. This review process was managed by the ANR Associate Editor for Human and Community Development.

web-12/09-LR/CR 